\title{
3'-Demethyldihydromaldoxin and dihydromaldoxin, two anti-inflammtory diaryl ethers from a Steganospora species
}

\begin{abstract}
Dominik Schreiber ${ }^{1}$, Mathias Jung ${ }^{2}$, Louis P Sandjo ${ }^{3}$, Johannes C Liermann ${ }^{3}$, Till Opatz ${ }^{3}$ and Gerhard Erkel ${ }^{1}$
CXCL10 (IP-10) is a highly inducible chemoattractant, which contributes to the recruitment of inflammatory cells such as macrophages and T-lymphocytes and thereby has important roles in chronic inflammatory conditions. In a search for new inhibitors of CXCL10 expression in MonoMac6 (MM6) cells, the new diaryl ether 3'-demethyldihydromaldoxin (1) along with the known compound dihydromaldoxin (2), were isolated from fermentations of a Steganospora species. The structures of the compounds were elucidated by a combination of one- and two-dimensional NMR spectroscopy and mass spectrometry.

Compounds (1) and (2) inhibited lipopolysaccharide (LPS)/interferon- $\gamma$ (IFN- $\gamma$ )-induced CXCL10 promoter activity in transiently transfected MM6 cells in a dose-dependent manner with $\mathrm{IC}_{50}$ values of $39-41 \mu \mathrm{m}$ and also reduced LPS/IFN- $\gamma$-induced CXCL10 protein synthesis and excretion.
\end{abstract}

The Journal of Antibiotics (2012) 65, 473-477; doi:10.1038/ja.2012.46; published online 13 June 2012

Keywords: CXCL10; 3'-demethyldihydromaldoxin; inhibitor

\section{INTRODUCTION}

Chemokine (C-X-C motif) ligand $10 \quad$ (CXCL10)/interferon- $\gamma$ (IFN- $\gamma$ )-inducible protein 10 (IP-10) is a small molecule that is secreted mainly by monocytes, fibroblasts and endothelial cells in response to diverse stimuli, such as IFN- $\gamma$, lipopolysaccharide (LPS), interleukin- $1 \beta$ (IL-1 $\beta$ ) and viral infection. The biological function of CXCL10 involves the recruitment of monocytes, macrophages and $\mathrm{T}$ cells to sites of inflammation. CXCL10 also participates in the regulation of T-cell responses due to modulation of T-cell proliferation in response to an antigenic challenge and favoritism of Th1-type cytokine production while downregulating Th2 cytokines. Although essential for effective host defense against infections, an increased expression of CXCL10 may also contribute to the induction and exacerbation of chronic inflammatory reactions associated to graft rejection or allergic and autoimmune diseases such as asthma, chronic obstructive pulmonary disease, acute inflammation in response to pathogens, inflammatory bowel diseases as well as rheumatoid arthritis. ${ }^{1,2}$ Therefore, CXCL10 might be an attractive target for the development of new therapeutics against various chronic inflammatory and autoimmune diseases. ${ }^{3}$ A screening of fungal extracts inhibiting LPS/IFN- $\gamma$-induced CXCL10 promoter-dependent reporter gene activity in transiently transfected MonoMac6 (MM6) cells, led to the isolation of the new diaryl ether $3^{\prime}$-demethyldihydromaldoxin (1) along with its known relative dihydromaldoxin (2) from fermentations of the fungus Steganospora sp.
Diaryl ethers are found as common metabolites in marine sponges, lichens, plants and fungi. Dihydromaldoxin, a chlorinated derivative of asterric acid, as well as various other chlorinated diaryl ethers have been isolated from different members of the genus Aspergillus, Penicillium, Xylaria and Pestalotiopsis. ${ }^{4-6}$ Asterric acid has been described to be the first non-peptidic inhibitor of the endothelin receptor and dechlorodihydromaldoxin and dihydromaldoxin were found to selectively inhibit endothelin- 1 binding to endothelin type A receptor with $\mathrm{IC}_{50}$ values of 1.5 and $20 \mu \mathrm{M}$, respectively. ${ }^{7,8}$ These compounds also inhibit the increase in intracellular $\mathrm{Ca}^{2+}$ concentration elicited by $1 \mathrm{~nm}$ endothelin- 1 in A10 cells. ${ }^{8}$ In addition, the asterric acid derivatives methyl asterric acid, methyl 3-chloroasterric acid and methyl 3,5-dichloroasterric acid exerted inhibitory activity on VEGF-induced capillary-like tube formation of human umbilical vein endothelial cells in vitro. ${ }^{9}$ Herein, we describe the fermentation, structure elucidation, and anti-inflammatory activities of $3^{\prime}$-demethyldihydromaldoxin (1) in comparison with dihydromaldoxin (2).

\section{RESULTS AND DISCUSSION}

Identification and structure elucidation

3'-Demethyldihydromaldoxin (1) and dihydromaldoxin (2) (Figure1) were isolated from the culture fluid extract by bioactivity-guided fractionation as described in the experimental section.

\footnotetext{
${ }^{1}$ Department of Molecular Biotechnology and Systems Biology, University of Kaiserslautern, Kaiserslautern, Germany; ${ }^{2}$ Institute of Biotechnology and Drug Research (IBWF), Kaiserslautern, Germany and ${ }^{3}$ nstitute of Organic Chemistry, University of Mainz, Mainz, Germany

Correspondence: Dr G Erkel, Department of Molecular Biotechnology and Systems Biology, University of Kaiserslautern, Paul-Ehrlich-Strasse 23, D-67663 Kaiserslautern, Germany.

E-mail: erkel@rhrk.uni-kl.de

Received 1 February 2012; revised 23 April 2012; accepted 15 May 2012; published online 13 June 2012
} 


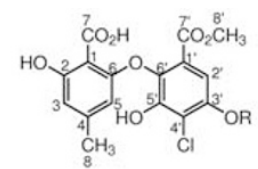

1: $\mathrm{R}=\mathrm{H}, 3^{\prime}$-Demethyldihydromaldoxin

2: $\mathrm{R}=\mathrm{CH}_{3}$, Dihydromaldoxin

Figure 1 Structures of Compounds (1) and (2).

Table $1{ }^{1} \mathrm{H}(400 \mathrm{MHz})$ and ${ }^{13} \mathrm{C}(100 \mathrm{MHz})$ NMR data

\begin{tabular}{|c|c|c|c|c|c|c|}
\hline \multirow[b]{2}{*}{ Position } & \multicolumn{2}{|c|}{$\begin{array}{l}\text { Compound } 1 \\
\qquad \mathrm{CD}_{3} \mathrm{CN}\end{array}$} & \multicolumn{2}{|c|}{$\begin{array}{c}\text { Asterric acid, } \\
\qquad \mathrm{CD}_{3} \mathrm{OD}\end{array}$} & \multicolumn{2}{|c|}{$\begin{array}{c}\text { Dihydromaldoxin (RES- } \\
1214-2)^{8}, \text { DMSO-d }_{6}\end{array}$} \\
\hline & $\delta_{H}$ & $\delta_{C}$ & $\delta_{H}$ & $\delta_{C}$ & $\delta_{H}$ & $\delta_{C}$ \\
\hline 1 & - & 100.9 & - & 104.8 & - & 105.0 \\
\hline 2 & - & 164.7 & - & 164.3 & - & 159.8 \\
\hline 3 & $6.56(1 \mathrm{H}, \mathrm{s})$ & 113.7 & $6.44(1 \mathrm{H}, \mathrm{s})$ & 111.8 & $6.39(1 \mathrm{H}, \mathrm{s})$ & 110.7 \\
\hline 4 & - & 148.6 & - & 145.4 & - & 143.4 \\
\hline 5 & $6.01(1 \mathrm{H}, \mathrm{s})$ & 106.3 & $5.78(1 \mathrm{H}, \mathrm{s})$ & 106.3 & $5.73(1 \mathrm{H}, \mathrm{s})$ & 105.2 \\
\hline 6 & - & 158.0 & - & 161.1 & - & 157.8 \\
\hline 7 & - & 171.7 & - & 167.6 & - & 170.4 \\
\hline 8 & $2.16(3 \mathrm{H}, \mathrm{s})$ & 21.9 & $2.14(3 \mathrm{H}, \mathrm{s})$ & 21.9 & $2.09(3 \mathrm{H}, \mathrm{s})$ & 21.3 \\
\hline $1^{\prime}$ & - & 124.1 & - & 127.0 & - & 123.0 \\
\hline $2^{\prime}$ & $7.41(1 \mathrm{H}, \mathrm{s})$ & 113.7 & $6.82(1 \mathrm{H}, \mathrm{s})$ & 106.2 & $7.01(1 \mathrm{H}, \mathrm{s})$ & 103.1 \\
\hline $3^{\prime}$ & - & 149.1 & - & 136.7 & - & 152.4 \\
\hline $4^{\prime}$ & - & 113.5 & $6.94(1 \mathrm{H}, \mathrm{s})$ & 109.3 & - & 114.1 \\
\hline $5^{\prime}$ & - & 146.6 & - & 155.3 & - & 148.2 \\
\hline $6^{\prime}$ & - & 139.4 & - & 156.7 & - & 136.0 \\
\hline $7^{\prime}$ & - & 170.3 & - & 167.6 & - & 164.6 \\
\hline $8^{\prime}$ & $3.95(3 \mathrm{H}, \mathrm{s})$ & 53.7 & $3.78(3 \mathrm{H}, \mathrm{s})$ & 52.7 & $3.65(3 \mathrm{H}, \mathrm{s})$ & 52.2 \\
\hline $9^{\prime}$ & & & $3.72(3 \mathrm{H}, \mathrm{s})$ & 56.8 & $3.89(3 \mathrm{H}, \mathrm{s})$ & 56.4 \\
\hline
\end{tabular}

Compound (1) was obtained as yellowish solid and its molecular formula $\mathrm{C}_{16} \mathrm{H}_{13} \mathrm{ClO}_{8}$ was determined on the basis of HR-ESI-MS which gave a pseudo-molecular ion at $\mathrm{m} / z 391.0199$ (calculated $391.0191)[\mathrm{M}+\mathrm{Na}]^{+}$. This formula requires 10 degrees of unsaturation, and the presence of chlorine was reflected by the characteristic isotope pattern. The IR spectrum showed bands for a carboxylic acid function $\left(3496,1692 \mathrm{~cm}^{-1}\right)$, an ester group $\left(1683 \mathrm{~cm}^{-1}\right)$ and an aromatic ring $\left(1579 \mathrm{~cm}^{-1}\right)$. The ${ }^{1} \mathrm{H}$ - and ${ }^{13} \mathrm{C}-\mathrm{NMR}$ spectra (Table 1 ) exhibited resonances attributable to one methyl, one methoxy and three aromatic methine groups. Analysis of diagnostic HMBC correlations and the comparison of the chemical shifts with those of asterric acid ${ }^{8}$ indicated the presence of two benzoic acid moieties linked in form of a diaryl ether and suggested a close structural similarity to dihydromaldoxin. Thus, some neighboring and longrange correlations (Figure 2) were detected in the HMBC spectrum from $\mathrm{H}-3$ ( $\delta 6.56)$ to $\mathrm{C}-1$ ( $\delta 100.9), \mathrm{C}-2$ ( $\delta 164.7), \mathrm{C}-5(\delta 106.3), \mathrm{C}-7$ $(\delta$ 171.7) and C-8 $(\delta$ 21.9). The same feature was observed between $\mathrm{H}-5(\delta$ 6.01) and the carbons C-1 ( $\delta$ 100.9), C-3 ( $\delta$ 113.7), C-4 $(\delta$ 148.6), C-6 $(\delta 158.0), C-7(\delta 171.7)$ and C-8 $(\delta 21.9)$. Further cross peaks between $\mathrm{H}-2^{\prime}\left(\delta\right.$ 7.41) and the carbons $\mathrm{C}-1^{\prime}\left(\delta\right.$ 124.1), C-3 $3^{\prime}$ $\left(\delta\right.$ 149.1), C-4' $\left(\delta\right.$ 113.5), C-5' $\left(\delta\right.$ 146.6), C-6 ${ }^{\prime}$ ( $\delta$ 139.4), and C-7 ${ }^{\prime}$ $(\delta$ 170.3) showed the difference between 1 and asterric acid to be the presence of a chlorine at C- $4^{\prime}$ of compound (1); besides, the presence of a hydroxyl function at $\mathrm{C}-3^{\prime}$ instead of a $\mathrm{MeO}$ group distinguishes its structure from that of dihydromaldoxin. The NOESY contact

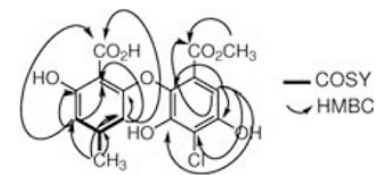

Figure 2 COSY and HMBC correlations of compound (1).

between the methoxy protons at $\delta 3.95$ and $\mathrm{H}-2^{\prime}(\delta 7.41)$ permitted the location of the ester function at $\mathrm{C}-7^{\prime}$, the aromatic methyl group exhibited only trivial NOE contacts to both neighboring protons.

Compound (2) was described before as RES-1214-2, ${ }^{8}$ dihydromaldoxin $^{5}$ and pestheic acid. ${ }^{10}$

\section{Biological activities}

In order to identify active compounds and to characterize their influence on CXCL10 expression, we used a human CXCL10 promoter-dependent transcriptional reporter in transiently transfected monocytic MM6 (MM6) cells, which reflects the activation of the transcription factors binding to the regulatory sites of the CXCL10 gene. ${ }^{11}$ Cells of the monocytic system (macrophages, monocytes) form a central part in immune defense by presenting processed antigen to $\mathrm{T}$ cells, phagocytosis of foreign material and orchestrating the immune response by secretion of cytokines. Typically, these cells, when triggered by an immunogen, produce proinflammtory cytokines (for example, tumor necrosis factor- $\alpha$, interleukin-1 $\beta$, interleukin-6), chemokines (for example, CXCL10, CXCL8) and proinflammatory enzymes (for example, COX-2). ${ }^{12}$ Transfection of MM6 cells with a hCXCL10 promoter-driven luciferase reporter plasmid and stimulation with $1 \mu \mathrm{g} \mathrm{ml}^{-1}$ LPS and $10 \mathrm{ng} \mathrm{ml}^{-1}$ IFN- $\gamma$ increased luciferase activity 8-10 fold compared with non-stimulated cells. As shown in Figure $3 \mathrm{a}$, the inducible promoter activity was dose dependently inhibited by $3^{\prime}$-demethyldihydromaldoxin (1) and dihydromaldoxin (2) with $\mathrm{IC}_{50}$ values of 41 and $39.2 \mu \mathrm{M}\left(15 \mu \mathrm{g} \mathrm{ml}^{-1}\right)$, respectively. The constitutive activity of the EF-1 $\alpha$-promoter-driven expression of the reporter gene renilla luciferase was not significantly affected up to a concentration of $50 \mu \mathrm{g} \mathrm{ml}^{-1}$ of compound (1) and (2) (135 and $131 \mu \mathrm{M}$, respectively) indicating that the compounds do not interfere with transcription in a general manner. The NF- $\kappa \mathrm{B}$ pathway has been shown to be an essential modulator of the transcription of chemokine genes such as CXCL10. ${ }^{13,14}$ We therefore investigated the effect of (1) and (2) on NF- $\kappa B$-driven expression of the reporter gene luciferase in LPS/IFN$\gamma$-stimulated MM6 cells. As shown in Figure 3b, both compounds inhibited the NF- $\kappa \mathrm{B}$-dependent expression of the reporter gene with $\mathrm{IC}_{50}$ values around $27 \mu \mathrm{M}\left(10 \mu \mathrm{g} \mathrm{ml}^{-1}\right)$. In addition to NF- $\kappa B$, the response of the $972 \mathrm{bp}$ CXCL10 promoter construct largely depends on three distal interferon-stimulated response elements (ISRE) and two Stat recognition sites. ${ }^{15}$ We therefore investigated the effect of 1 and 2 on Stat 1 and ISRE-driven expression of the reporter gene luciferase in LPS/IFN- $\gamma$-stimulated MM6 cells. As shown in Figure 3c, the ISRE-dependent expression of the reporter gene was inhibited by both compounds with $\mathrm{IC}_{50}$ values of $59 \mu \mathrm{M}$ dihydromaldoxin (2) and $90 \mu \mathrm{M} 3$ '-demethyldihydromaldoxin (1), whereas the Stat1-dependent transcriptional reporter was not significantly affected.

To investigate the effect of $3^{\prime}$-demethyldihydromaldoxin (1) and dihydromaldoxin (2) on the inducible transcription of the CXCL10 gene, quantitative real-time PCR experiments were performed with total RNA isolated from cells stimulated with LPS/IFN- $\gamma$ for $4 \mathrm{~h}$ and treated with different concentrations of test compounds as described in the Materials and methods section. Values are expressed as relative 
mRNA content of induced versus uninduced cells (100\%), and induced and compound treated versus induced and untreated cells, each corrected for the constitutive expressed housekeeping gene $G A P D H$ as reference determined in the same sample in parallel. As shown in Figure 4, stimulation of MM6 cells with LPS and IFN- $\gamma$ resulted in a strong upregulation ( $\sim 1250$-fold; $100 \%)$ of the mRNA level for CXCL10. Uninduced cells did not produce detectable amounts of CXCL10 mRNA. At a concentration of $26.2 \mu \mathrm{m}$, dihydromaldoxin (2) significantly downregulated the mRNA level of
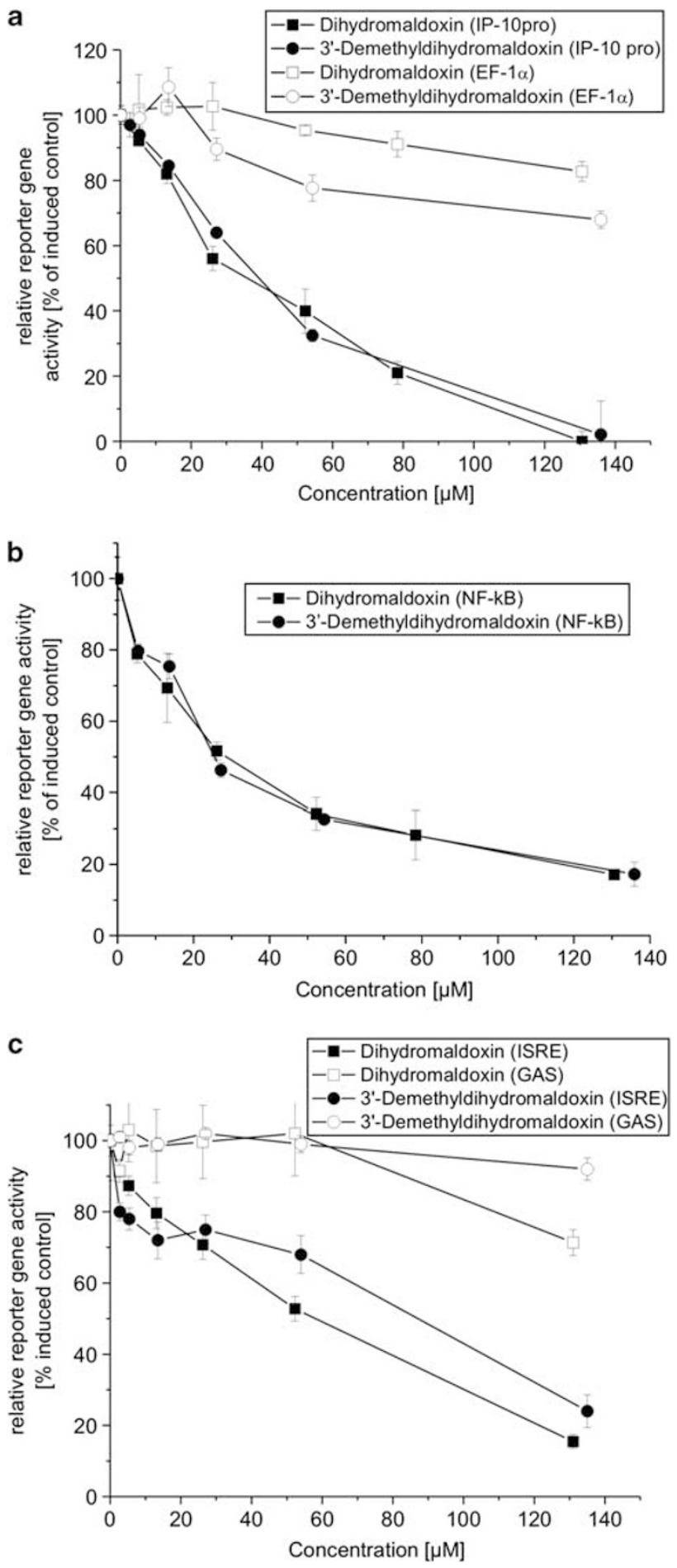

CXCL10 in LPS/IFN- $\gamma$-induced MM6 cells around 50\%, whereas 3 -demethyldihydromaldoxin (1) reduced CXCL10 mRNA level to a lesser extent. The measured mRNA values for GAPDH did not vary significantly upon treatment of the cells with LPS/IFN- $\gamma$ or test compounds (data not shown).

In turn, we analyzed the influence of (1) and (2) on CXCL10 synthesis and excretion in MM6 cells, which release significant amounts of CXCL10 following LPS/IFN- $\gamma$ treatment. As shown in Figure 5, pretreatment of MM6 cells with various concentrations of both compounds and stimulation with LPS/IFN- $\gamma$ for $16 \mathrm{~h}$ resulted in a dose-dependent inhibition of CXCL10 synthesis, which was comparable to the results obtained in the quantitative real-time PCR assays. The above-mentioned results indicate that the fungal metabolites exert their inhibitory activities on the transcriptional level and thus results in a reduced protein level.

Cytotoxic properties of (1) and (2) were evaluated against MM6 cells by measuring the reduction of the tetrazolium compound 2,3bis(2-methoxy-4-nitro-5-sulfophenyl)-2 $\mathrm{H}$-tetrazolium-5-carboxanilide sodium (XTT) into a colored formazan, which is directly proportional to the number of living cells in culture. No significant cytotoxic

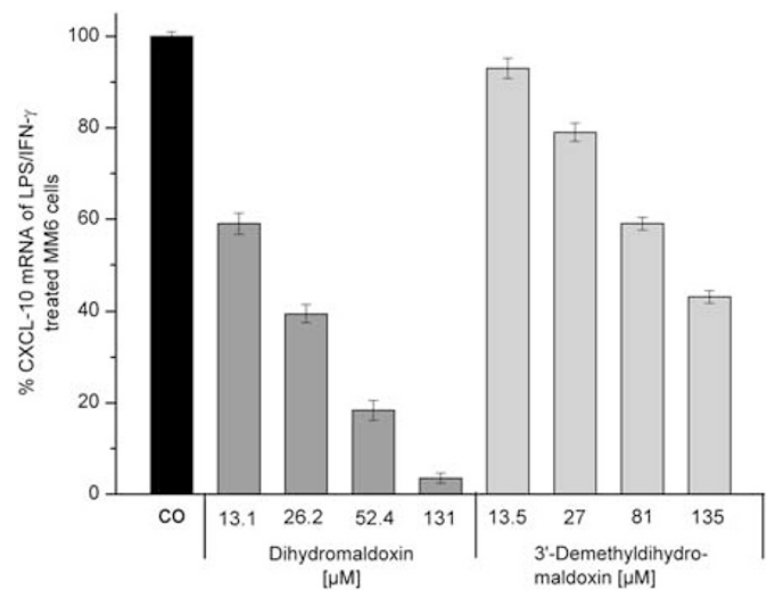

Figure 4 Effect of (1) and (2) on mRNA levels of CXCL10 in LPS/IFN- $\gamma$ stimulated MonoMac6 (MM6) cells. Values represent the relative mRNA levels of stimulated versus unstimulated cells as control (100\%) and compound pretreated and stimulated versus untreated, stimulated cells, corrected for GAPDH as reference determined in the same sample in parallel. Data are shown as mean values \pm s.e.m. of three independent experiments.

Figure 3 Effect of (1) and (2) on CXCL10 promoter activity, NF-KB-, Stat1and ISRE-driven reporter gene expression. (a)MonoMac6 (MM6) cells were transiently transfected with a CXCL10- or EF1 $\alpha$-promoter-dependent reporter construct and stimulated with $1 \mu \mathrm{g} \mathrm{ml}^{-1}$ lipopolysaccharide (LPS) and $10 \mathrm{ng} \mathrm{ml}^{-1} \mathrm{IFN}-\gamma$ for $4 \mathrm{~h}$ with or without test compounds. Control (100\%): stimulation only. Results represent the mean \pm s.e.m. of at least three independent experiments. (b) MM6 cells were transiently transfected with a NF-kB-dependent reporter construct and stimulated with $1 \mu \mathrm{g} \mathrm{ml}^{-1}$ LPS and $10 \mathrm{ng} \mathrm{ml}^{-1}$ IFN- $\gamma$ for $4 \mathrm{~h}$ with or without test compounds. Control (100\%): stimulation only. Results represent the mean \pm s.e.m. of at least three independent experiments. (c) MM6 cells were transiently transfected with an ISRE-or GAS-dependent reporter construct and stimulated with $1 \mu \mathrm{gml}^{-1}$ LPS and $10 \mathrm{ngml}^{-1}$ IFN- $\gamma$ for $4 \mathrm{~h}$ with or without test compounds. Control (100\%): stimulation only. Results represent the mean \pm s.e.m. of at least three independent experiments. The expression of the reporter genes was determined as described in the experimental section. 


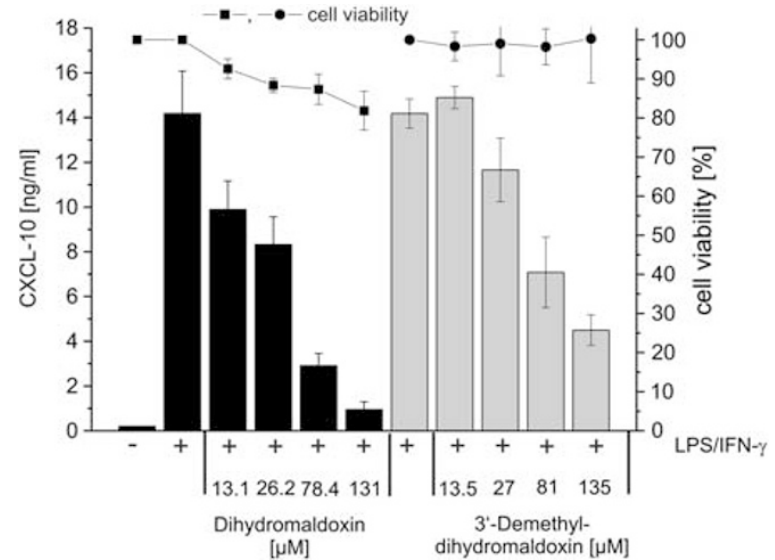

Figure 5 Effect of (1) and (2) on CXCL10-production and cell viability. MonoMac6 (MM6) cells were pretreated for $1 \mathrm{~h}$ with or without the test compounds and stimulated with $1 \mu \mathrm{gml} \mathrm{ml}^{-1}$ lipopolysaccharide (LPS) and $10 \mathrm{ng} \mathrm{ml}^{-1}$ IFN- $\gamma$ for additional $24 \mathrm{~h}$. CXCL10 concentrations in cell supernatants were determined by ELISA. Cell viability was determined by XTT colorimetric assay. Data are shown as mean values \pm s.e.m. of three independent experiments.

activities against MM6 cells could be observed up to $50 \mu \mathrm{g} \mathrm{ml}^{-1}$ (131-135 $\mu \mathrm{M})$ of both compounds during a 24-h incubation period. In addition, both compounds exhibited no antibacterial or antifungal activities up to a concentration of $50 \mu \mathrm{g}$ per disc in an agar diffusion assay.

\section{MATERIALS AND METHODS}

\section{General procedures}

${ }^{1} \mathrm{H}$ NMR $(400 \mathrm{MHz})$ and ${ }^{13} \mathrm{C}$ NMR $(101 \mathrm{MHz})$ were recorded with a Bruker Avance-II spectrometer (Bruker Daltonik, Bremen, Germany) equipped with a $5-\mathrm{mm}$ BBO probe head. The spectra were measured in $\mathrm{CDCl}_{3}$ and the chemical shifts were referenced to the residual solvent signal $\left(\delta_{\mathrm{H}}=7.26\right.$ p.p.m., $\delta_{\mathrm{C}}=77.16$ p.p.m.). ${ }^{16} \mathrm{APCI}-\mathrm{MS}$ spectra were measured from a solution of the analyte in $\mathrm{MeCN} / \mathrm{H}_{2} \mathrm{O}$ with a Hewlett Packard MSD 1100 (Agilent Technologies, Waldbronn, Germany) using an evaporator temperature of $400{ }^{\circ} \mathrm{C}$, a drying gas temperature of $350^{\circ} \mathrm{C}$ at a flow of 61 per $\mathrm{h}\left(\mathrm{N}_{2}\right)$. In positive ionization mode, the capillary voltage amounted to $3.5 \mathrm{kV}$, the corona discharge current was $4 \mu \AA$. In negative ionization mode, the capillary voltage amounted to $2.2 \mathrm{kV}$, the corona discharge current was $6 \mu \AA$. ESI-HRMS data were measured from a solution of the analyte in acetonitrile with a Waters Q-TOF-Ultima 3 (Waters GmbH, Eschborn, Germany) equipped with a LockSpray interface (tri- $n$-octylamine as external reference). IR and UV spectra were measured with a Bruker IFS48 FTIR spectrometer (Bruker Daltonik) and a Perkin-Elmer Lambda-16 spectrophotometer (Perkin-Elmer, Rodgau, Germany), respectively. The optical rotation was measured on a Perkin-Elmer 241 polarimeter at 578 and $546 \mathrm{~nm}$ and extrapolated to $589 \mathrm{~nm}$ using Drude's equation.

\section{Culturing and isolation of metabolites}

Steganospora sp. strain IBWFE07110 was isolated from a twig of Robinia pseudoacacia collected in Germany. A three-step ethanol, sodium hypochlorite and ethanol treatment was used to isolate the endophytic fungus. The strain is deposited in the culture collection of the Institute of Biotechnology and Drug Research (IBWF e.V.), Kaiserslautern, Germany. Steganospora sp. strain IBWFE07110 showed all characteristics of the genus, the species, however, could not be unequivocally determined. Owing to the lack of similar sequences, identification of the strain to the species level by ITS sequence analysis of the ITS1-5.8S rDNA-ITS2 region of nuclear DNA ${ }^{17}$ was not possible. For maintenance, the fungus was grown on HA agar slants (yeast extract $4 \mathrm{gl}^{-1}$, malt extract $10 \mathrm{gl}^{-1}$, glucose $4 \mathrm{gl}^{-1}$; the $\mathrm{pH}$ value was adjusted to 5.5 before autoclaving). Solid media contained $2 \%$ of agar. Well-grown seed cultures of the producing strain $(200 \mathrm{ml} \mathrm{HA}$ medium) were used to inoculate a Biolafitte C-6 fermenter containing 201 of malt extract medium $\left(20 \mathrm{gl}^{-1}\right.$ malt extract, $\mathrm{pH}$ 5.5) with aeration (3.01 air $\left.\mathrm{min}^{-1}\right)$ and stirring (120 r.p.m.) at $22^{\circ} \mathrm{C}$. The production of compounds (1) and (2) was detected by the inhibitory effect of various concentrations of a crude extract of the culture fluid in the CXCL10 promoter-dependent reporter gene assay as described below. The compounds were isolated from the culture fluid by bioactivity-guided fractionation using the CXCL10 transcriptional reporter assay in MM6 cells.

After $306 \mathrm{~h}$, the culture fluid was separated from the mycelia by filtration, extracted twice with an equal volume of EtOAc and dried over $\mathrm{Na}_{2} \mathrm{SO}_{4}$. After concentration in vacuo, the crude extract $(9.5 \mathrm{~g})$ was fractionated by subsequent chromatography on silica gel (Merck 60, eluent: cyclohexane : EtOAc, $40: 60 \mathrm{v} / \mathrm{v})$. The enriched fraction $(2.5 \mathrm{~g})$ was then chromatographed over silicic acid (SIL-A-200, Sigma-Aldrich, Taufkirchen, Germany) using cyclohexane/EtOAc gradient as the mobile phase. The enriched fraction $(355.2 \mathrm{mg})$ was further purified on a CHROMABOND C18 column (Macherey-Nagel, Düren, Germany) with a $\mathrm{H}_{2} \mathrm{O} / \mathrm{MeCN}$ gradient to yield $210 \mathrm{mg}$ of enriched product. Further purification was achieved by semipreparative HPLC on a phenyl reversed phase column (Zorbax Eclipse XDB Phenyl, $21.2 \times 150 \mathrm{~mm}^{2}, 5 \mu \mathrm{M}$, Agilent Technologies) using $\mathrm{HCOOH} / \mathrm{H}_{2} \mathrm{O}$ ( $63 \%$ ( $0.3 \mathrm{vol} \% \mathrm{HCOOH}$ ): $37 \% \mathrm{MeCN}$; flow-rate $21 \mathrm{ml} \mathrm{min}^{-1}$ ) as eluent to

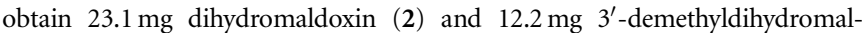
doxin (1).

$3^{\prime}$-Demethyldihydromaldoxin (1): slightly yellow amorphous powder; $\mathrm{Mp}$ 222-224 ${ }^{\circ} \mathrm{C}$; ESI-MS: $\mathrm{m} / \mathrm{z} 369[\mathrm{M}+\mathrm{H}]^{+}, 351\left[\mathrm{M}+\mathrm{H}-\mathrm{H}_{2} \mathrm{O}\right]^{+}, 319[\mathrm{M}+\mathrm{H}-$ $\left.\mathrm{CH}_{3} \mathrm{Cl}\right]^{+}$; IR $\vee\left(\mathrm{cm}^{-1}\right): 3497,2958,2928,1692,1683,1579 ; \mathrm{UV}, \lambda_{\max }(\log \varepsilon$, MeCN): 211 (4.40), 250 (3.99), 330 (3.61) nm, NMR data: see Table 1.

\section{Biological assays}

Cell culture and cytotoxicity assay. MM6 (DSMZ ACC124) cells were maintained in RPMI 1640 medium containing $25 \mathrm{~mm}$ HEPES buffer, $2 \mathrm{~mm}$ L-glutamine, supplemented with $10 \% \mathrm{FCS}, 100 \mathrm{u} \mathrm{ml}^{-1}$ penicillin and $100 \mu \mathrm{g} \mathrm{ml}^{-1}$ streptomycin at $37^{\circ} \mathrm{C}$ and $5 \% \mathrm{CO}_{2}$ in a humidified atmosphere. The cytotoxicity against MM6 cells was determined in an XTT-based cell viability assay. ${ }^{18}$ The assays for antimicrobial activity were carried out as described previously. ${ }^{19}$ Human recombinant IFN- $\gamma$ (R\&D Systems, Wiesbaden, Germany) and LPS (Sigma-Aldrich) was dissolved in RPMI 1640 medium containing $0.5 \%$ FCS at a final concentration of 10 and $1 \mathrm{mg} \mathrm{ml}^{-1}$, respectively. Stock solutions of the test compounds were prepared in $\mathrm{EtOH}$ and diluted into the cell culture medium to give a final concentration $<0.1 \%$ of the solvent.

Reporter gene assays. The human IP-10 Promoter $(-875$ to +97$)$ was amplified by PCR from genomic DNA extracted from MM6 cells. The PCR product was cloned into the pGL4-luc basic vector (Promega, Mannheim, Germany) to generate the firefly luciferase reporter plasmid pGL4-IP10pro. The plasmid pRL-EF- $1 \alpha$ for normalizing transfection efficiency was obtained from Promega. The NF-кB-, Stat1- and IRF-driven reporter plasmids pNFкBLuc, pGAS-Luc and pISRE-Luc were obtained from Clontech (Saint-Germainen-Laye, France). Transient transfections of MM6 cells were performed by electroporating (BioRad, Munich, Germany; Gen Pulser) $3 \times 10^{7}$ cells ml $^{-1}$ in $0.4 \mathrm{ml}$ RPMI 1640 medium containing $25 \mathrm{~mm}$ HEPES buffer together with $40 \mu \mathrm{g}$ of the indicated plasmids at $200 \mathrm{~V}$ and $975 \mu \mathrm{F}^{20}$ After electroporation the cells were seeded at $1 \times 10^{6}$ cells ml $^{-1}$ RPMI 1640 medium containing $10 \%$ FCS in a 24-well plate with and without test compounds and luciferase expression was induced with $1 \mu \mathrm{g} \mathrm{ml}^{-1}$ LPS and $10 \mathrm{ng} \mathrm{ml}^{-1}$ IFN- $\gamma$. Luciferase activity was measured $4 \mathrm{~h}$ after induction using the Dual-Glo luciferase assay system (Promega) according to the manufacturer's instructions with a luminometer.

Quantitative real-time PCR. For qRT-PCR analysis, MM6 cells were starved for $16 \mathrm{~h}$ in RPMI 1640 medium with $0.5 \%$ FCS. Afterwards, the cells were plated into six-well plates at a density of $3 \times 10^{6}$ cells per well. After treatment with test compounds for $1 \mathrm{~h}$, the cells were induced with $1 \mu \mathrm{g} \mathrm{ml}^{-1}$ LPS and 
$10 \mathrm{ng} \mathrm{ml}^{-1}$ IFN- $\gamma$ for $4 \mathrm{~h}$. Following stimulation, the cells were lysed and total cellular RNA was prepared by using the RNeasy mini kit obtained from Qiagen (Hilden, Germany). First strand cDNA was generated using the RevertAid H Minus First Strand cDNA Synthesis Kit (Fermentas, St LeonRoth, Germany). Gene expression was quantified from $300 \mathrm{ng}$ cDNA using the $5 x$ Hot Start Taq EvaGreen qPCR Mix (Axon, Kaiserslautern, Germany) according to manufacturer's suggestions with gene-specific primers for human CXCL10 (Genbank Accession NM001565) forward: 5'-TGAGCCTACAGCA GAGGAA- $3^{\prime}$ and reverse: $5^{\prime}$-TACTCCTTGAATGCCACTTAGA- $3^{\prime}$ (size of the PCR product is $102 \mathrm{bp}$ ) and GAPDH (Genbank Accession M33197) forward: $5^{\prime}$-CCTCCGGGAAACTGTGG- $3^{\prime}$ and reverse: $5^{\prime}$-AGTGGGGACACGGAAG- ${ }^{\prime}$ (size of the PCR product is $140 \mathrm{bp}$ ). All primers were manufactured by MWGBiotech AG (Ebersberg, Germany). Measurements were done using the CFX96 detection system (BioRad) with the following protocol: initial activation of HotStar Taq DNA polymerase at $95^{\circ} \mathrm{C}$ for $15 \mathrm{~min}, 45$ cycles of $94{ }^{\circ} \mathrm{C}$ for $15 \mathrm{~s}$, annealing at $56^{\circ} \mathrm{C}$ for $30 \mathrm{~s}$, extension/detection at $72{ }^{\circ} \mathrm{C}$ for $30 \mathrm{~s}$. Relative mRNA amounts were determined using the mathematical model for relative quantification in real-time PCR proposed by $\mathrm{Pfaff}^{21}$ in which the relative expression ratio is calculated from the real-time PCR efficiencies and the crossing point deviation of an unknown sample versus glyceraldehyde-3phosphate dehydrogenase $(G A P D H)$ as control housekeeping gene.

ELISA. For analyzing CXCL10 synthesis MM6 cells were starved for $16 \mathrm{~h}$ in RPMI 1640 medium containing $0.5 \%$ FCS, pretreated for $1 \mathrm{~h}$ with the test compound and subsequently induced with $1 \mu \mathrm{g} \mathrm{ml}^{-1}$ LPS and $10 \mathrm{ng} \mathrm{ml}^{-1}$ IFN- $\gamma$ for additional $24 \mathrm{~h}$. Subsequently, the cells were centrifuged and the cell culture supernatant was analyzed using the CXCL10 ELISA kit (R\&D Systems) according to the manufacturer's instructions.

\section{CONCLUSION}

In summary, we have identified the new diaryl ether 3 -demethyldihydromaldoxin (1) along with the known dihydromaldoxin (2) as inhibitors of CXCL10 expression from fermentations of a Steganospora species. Thus, diaryl ethers of this type may serve as a starting point for the development of transcriptionally based inhibitors of chronic inflammatory disorders.

\section{CONFLICT OF INTEREST}

The authors declare no conflict of interest.

\section{ACKNOWLEDGEMENTS}

This work was supported by a grant from the Stiftung Rheinland-Pfalz für Innovation and by the Naturstoffzentrum Rheinland-Pfalz. We thank A Meffert for expert technical assistance.
1 Groom, J. R. \& Luster, A. D. CXCR3 ligands: redundant, collaborative and antagonistic functions. Immunol. Cell Biol. 89, 207-215 (2011).

2 Lee, E. Y., Lee, Z.-H. \& Song, Y. W. CXCL10 and autoimmune diseases. Autoimmun. Rev. 8, 379-383 (2009)

3 Liu, M., Guo, S., Hibbert, J. M., Jain, V., Singh, N., Wilson, N. O. \& Stiles, J. K. CXCL10/IP-10 in infectious diseases pathogenesis and potential therapeutic implications. Cytokine Growth Factor Rev. 22, 121-130 (2011).

4 Hargreaves, J., Park, J., Ghisalberti, J. E., Sivasithamparam, K., Skelton, B. W. \& White, A. H. New chlorinated diphenyl ethers from an Aspergillus species. J. Nat. Prod. 65, 7-10 (2002).

5 Adeboya, M. O., Edwards, R. L., Lassøe, T., Maitland, D. J., Shields, L. \& Whalley, A. J. S. Metabolites of the higher fungi. Part 29. Maldoxin, maldoxone, dihydromaldoxin, isodihydromaldoxin and dechlorodihydromaldoxin. A spirocyclohexadienone, a depsidone and three diphenyl ethers: keys in the depsidone biosynthetic pathway from a member of the fungus genus Xylaria. J. Chem. Soc. Perkin Trans. 1, 1419-1425 (1996).

6 Liu, L. Bioactive metabolites from the plant endophyte Pestalotiopsis fici. Mycology 2, 37-45 (2011).

7 Ohashi, H., Akiyama, H., Nishikori, K. \& Mochizuki, J. Asterric acid, a new endothelin binding inhibitor. J. Antibiot. 45, 1684-1685 (1992).

8 Ogawa, T., Ando, K., Aotani, Y., Shinoda, K., Tanaka, T., Tsukuda, E. \& Yoshida, M. \& Matsuda, Y. RES-1214-1 and -2, novel non-peptidic endothelin type A receptor antagonists produced by Pestalotiopsis sp. J. Antibiot. 48, 1401-1406 (1995).

9 Lee, H. J., Lee, J. H., Hwang, B. P., Kim, H. S. \& Lee, J. J. Fungal metabolites, asterric acid derivatives inhibit vascular endothelial growth factor (VEGF)-induced tube formation of HUVECs. J. Antibiot. 55, 552-556 (2002).

10 Shimada, A., Takahashi, I., Kawano, T. \& Chloroisosulochrin, Kimura Y. chloroisosulochrin dehydrate, and pestheic acid, plant growth regulators, produced by Pestalotiopsis theae Z. Z. Naturforsch 56b, 797-803 (2001).

11 Tamassia, N., Calzetti, F., Ear, T., Cloutier, A., Gasperini, S., Bazzoni, F., McDonald, P. P. \& Cassatella, M. A. Molecular mechanisms underlying the synergistic induction of CXCL10 by LPS and IFN- $\gamma$ in human neutrophils. Eur. J. Immunol. 37, 2627-2634 (2007).

12 Erkel, G., Wisser, G. \& Anke, T. Influence of the fungal NF-кB inhibitor panepoxydone on inflammatory gene expression in MonoMac6 cells. Int. Immunopharmacol. 7, 612-624 (2007)

13 Richmond, A. NF-кB, chemokine gene transcription and tumor growth. Nat. Rev. Immunol. 2, 664-674 (2002).

14 Hagemann, T., Biswas, S. K., Lawrence, T., Sica, A. \& Lewis, C. E. Regulation of macrophage function in tumors: the multifaceted role of NF-kB. Blood 113, 3139-3146 (2009).

15 Spurrell, J. C. L., Wiehler, S., Zaheer, R. S., Sanders, S. P. \& Proud, D. Human airway epithelial cells produce IP-10 (CXCL10) in vitro and in vivo upon rhinovirus infection. Am. J. Physiol. Lung Cell Mol. Physiol. 289, L85-L95 (2005).

16 Gottlieb, H. E., Kotlyar, V. \& Nudelman, A. NMR chemical shifts of common laboratory solvents as trace impurities. J. Org. Chem. 62, 7512-7515 (1997).

17 White, T. J., Bruns, T., Lee, S. \& Taylor, J. Amplification and direct sequencing of fungal ribosomal RNA genes for phylogenetics. In PCR Protocols: A Guide to Methods and Applications (eds M. A., Innis, D. H., Gelfand, J. J., Sninsky \& T. J., White) 315-322 (Academic Press, San Diego, 1990).

18 Roehm, N. W., Rodgers, G. H., Hatfield, S. M. \& Glasebrook, A. L. An improved colorimetric assay for cell proliferation and viability utilizing the tetrazolium salt XTT. J. Immunol. Methods 142, 257-265 (1991).

19 Rether, J., Erkel, G., Sterner, O. \& Anke, T. Inhibition of TNF- $\alpha$ promoter activity and synthesis by A11-99-1, a new cyclopentenone from the ascomycete Mollisia melaleuca. Z. Naturforsch 60c, 478-484 (2005).

20 Jung, M., Triebel, S., Anke, T., Richling, E. \& Erkel, G. Influence of apple polyphenols on inflammatory gene expression. Mol. Nutr. Food Res. 53, 1263-1280 (2009).

21 Pfaffl, M. W. A new mathematical model for relative quantification in real-time RT-PCR. Nucleic Acid Res. 29, 2002-2007 (2001). 